$\xi=-1$

\title{
Rational Speculative Bubble Size in Hang Seng, S\&P500 and Nikkei 225 Index Trend from Year 1976 until 2016
}

\author{
Nurharyanti Borhan ${ }^{1 *}$, Nurfadhlina Abdul Halim¹, Wan Muhammad Amir W. Ahmad ${ }^{2}$, Mustafa Mamat ${ }^{3}$, Nor \\ Azlida Aleng', Kasypi Mokhtar ${ }^{4}$, Mohd Asrul Affendi Abdullah ${ }^{5}$ and Zailani Abdullah 6 \\ ${ }^{1}$ School of Informatics and Applied Mathematics, Universiti Malaysia Terengganu, 21030 Kuala Nerus, Terengganu, Malaysia. \\ ${ }^{2}$ School of Dental Sciences, Campus of Health, Universiti Sains Malaysia, 16150 Kubang Kerian, Kelantan, Malaysia. \\ ${ }^{3}$ Faculty of Informatics and Computing, Universiti Sultan Zainal Abidin, Gong Badak Campus, 21300 Kuala Terengganu, Terengganu, \\ Malaysia. \\ ${ }^{4}$ School of Maritime Business and Management, Universiti Malaysia Terengganu, 21300 Kuala Terengganu, Terengganu, Malaysia. \\ ${ }^{5}$ Department of Mathematics and Statistics, Universiti Tun Hussein Onn Malaysia, 86400 Parit Raja, Batu Pahat, Johor, Malaysia. \\ ${ }^{6}$ Faculty of Entrepreneurship and Business/Centre of Computing and Informatics, Universiti Malaysia Kelantan, City Campus, Locked \\ Bag 36, Pengkalan Chepa, 16100 Kota Baharu, Kelantan, Malaysia. \\ *Corresponding author E-mail: nurharyantihusna@gmail.com
}

\begin{abstract}
Rational speculative bubble size happens when the prices of an asset surpass its intrinsic value. This bubbles are harmful when burst because its gives a big impact towards the economic. The aims of this study is to show the size of rational speculative bubble existed from year 1976 until 2016. The period are separated into four which are the first cycle is from 1/11976 to 6/12/1987, the second cycle happen in 7/12/1987 to $12 / 8 / 1998,13 / 8 / 1998$ to $26 / 10 / 2008$ for the third cycle and 27/10/2008 to 31/12/2016 for the fourth cycle. This study is also emphasizing on the trend of the rational speculative bubble from one cycle to another cycle. This bubbles size was studied in three markets which are Hang Seng, S\&P 500 and Nikkei 225 by using generalized Johansen-Ledoit-Sornette model. The difference
\end{abstract}

Keywords: Financial Bubble; Generalized Johansen-Ledoit-Sornette; Speculative Bubble; Trend.

\section{Introduction}

Some investors said that the housing market in United States will not collapse because this market is considered as no harm and this market is the most profitable investment6. But when there was a financial crisis in the United States in 2008, this crisis has led all to fear. It was a worst financial crisis happened since 1929. The housing prices fell to $31.8 \%$ and even after two years, the unemployment was still high ${ }^{7}$.

The economic crisis is not something special for developed countries only. The developing countries are also very vulnerable to various types of banking, external debt, currency and inflation crisis that have taken place over the last few decades. The debt crisis caused many developing countries to experience a reces$\operatorname{sion}^{8}$.

Financial bubble is one of the financial crisis that will caused a big impact to the economic system. The bubbles burst caused many developed countries like the United States to suffer huge losses. The effect of the bubbles burst makes the country's economy becomes uncertain. It took quite a while to restore the economic downturn that caused by the bubble breakdown.

Rational speculative bubble is a condition where the prices of an asset surpass its intrinsic value. The burst of this bubble can cause a collapse of the economic system. This bubble exists when the asset started to be traded. Bubble size identification is necessary to ensure that the economy of a country is stable and economic crisis can be avoided.

Economic crisis that happen in Holland (Tulipmania), France (Missisippi) and United Kingdom (South Sea), should be desirable as a lesson so that the same mistake will not happen again. Tulipmania was the first financial bubble that happens in Holland on 1630. Tulips were purchased at low prices and sold when the prices increase. To one level, the shareholders began to sell even if nobody wants to buy. This the ongoing situation led to the onset of sales regardless of profit situation. Thus, the tulip market was collapsed in February 16371.

This same goes to Missisippi bubble ${ }^{2}$ and South Sea bubble ${ }^{3}$. When a business merely thinks of profit and not at risk and loss that will be encountered over a long period of time with the actions taken, this will lead to collapse of a company.

Production without regard to demand will cause huge losses. As well as bubbles, when the price of an asset is continuously increased regardless of the buyer's ability to purchase the asset in an uncertain economic environment may lead to an economic downturn.

As a result of rising prices, the price is set aside beyond the buyer's ability. The intrinsic value of an asset is difficult to identify 
with the presence of bubbles in the market. When there is a bubble burst then the asset value will return to its original value. However, the breakdown of the bubble will have a severe effects towards the country's economic growth.

\section{Generalized Johansen-Ledoit-Sornette}

Generalized Johansen-Ledoit-Sornette(GJLS) was built by A. Johansen, O. Ledoit and D. Sornette to represent about the dynamic of financial bubbles and crashes ${ }^{9}$. In this study, GJLS model is used to estimate the size of rational speculative bubble in Hang Seng, S\&P500 and Nikkei 225 Index market from 1976 until 2016.

By using GJLS, the intrinsic value can be estimated. This model not only can estimate the intrinsic value but also can detect the time of bubble crash and as well as crash non-linearity. This is why we choose GJLS compared to the Standard Johansen-LedoitSornette (SJLS), that only can identify and predict the financial bubbles and crash $^{4}$. The GJLS model can be shown as below.

$$
p t=p_{1}+\exp \left(A+B\left(t_{c}-t\right)^{\beta}+C \cos \left(\omega \log \left(t_{c}-t\right)+\phi\right)\right)
$$

Equation 1 is used to forecast the size of the rational speculative bubble for a particular time. Where $p t$ is the price for the time $\mathrm{t}$. $p_{1}$ as the intrinsic value and $\exp \left(A+B\left(t_{c}-t\right)^{\beta}+C \cos \left(\omega \log \left(t_{c}-t\right)+\phi\right)\right)$ refers to the size of rational speculative bubble size or also known as $\exp \left(F t_{L P P L}\right)$. In this study, only $\exp \left(F t_{L P P L}\right)$ part is used to estimate the size of speculative rational bubbles for major world markets which are Hang Seng, S\&P500 and Nikkei 225. Equation 2 shows the equation of the rational speculative bubble size that referred as $\mathrm{h}(\mathrm{t})^{9}$.

$$
h(t)=\exp \left(A+B\left(t_{c}-t\right)^{\beta}+C \cos \left(\omega \log \left(t_{c}-t\right)+\phi\right)\right)
$$

In equation 2 , the parameters are $A, B, C, t_{c}, \beta, \omega, \phi$ where $A, B$ and $C$ are the linear parameters and $t_{c}, \beta, \omega, \phi$ are the nonlinear parameters.

The value of $\omega$ was found by using three consecutive peaks which are $h, n$ and $f$ where $h<n<f$. The formula to find $\omega$ is $\omega=2 \prod / \ln (\rho)$ where $\rho=(n-h) /(f-n)$ and to calculate the value of $\phi$, the formula $\phi=\Pi-\omega \ln \left(t_{c}-t\right)$ was used. The illustration on the calculation of $\omega$ value is shown in Figure 1.

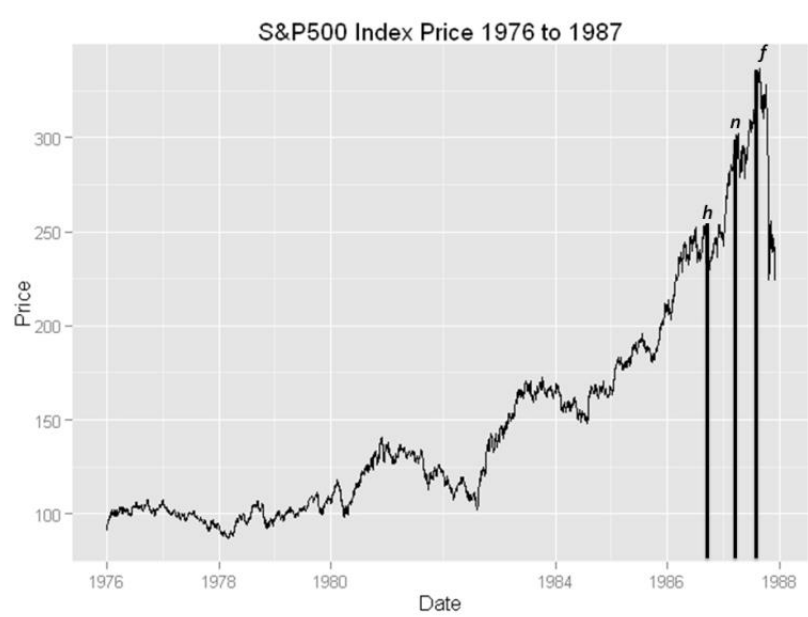

Figure 1. Example of the election of the consecutive peaks to find the $\omega$. Not all the value of $\omega$ can be used to find the rational speculative bubble size. It may be a lot and a simulation must be done to choose the best $\omega$ to find the bubbles.
The value of $A, B$ and $C$ can be estimate by using Ordinary Least Squares (OLS) method as shown below ${ }^{5}$

$\sum_{t=t_{1}}^{t_{n}}\left(\begin{array}{c}\ln p_{t} \\ f_{t} \ln p_{t} \\ g_{t} \ln p_{t}\end{array}\right)=\sum_{t=t_{1}}^{t_{n}}\left(\begin{array}{ccc}1 & f_{t} & g_{t} \\ f_{t} & f_{t}^{2} & f_{t} g_{t} \\ g_{t} & f_{t} g_{t} & g_{t}^{2}\end{array}\right)\left(\begin{array}{c}A \\ B \\ C\end{array}\right)$

The system of the equations above is rewrite in the matrix form as $X^{T} y=\left(X^{T} X\right) \beta$, where

$X=\left(\begin{array}{ccc}1 & f_{t} 1 & g_{t} 1 \\ \cdot & \cdot & \cdot \\ \cdot & \cdot & \cdot \\ \cdot & \cdot & \cdot \\ 1 & f_{t} n & g_{t} n\end{array}\right), y=\left(\begin{array}{c}\ln p_{t} 1 \\ \cdot \\ \cdot \\ \cdot \\ \ln p_{t} n\end{array}\right), \beta=\left(\begin{array}{c}A \\ B \\ C\end{array}\right)$

Then, the solution of $\hat{\beta}$ is given by $\left(X^{T} X\right)^{-1} X^{T} y$. The linear parameter which are $A, B$ and $C$ are solved by using $\hat{\beta}$ formula.

\section{Result}

Table 1 until Table 4 shows the values of the rational speculative bubble for the four cycles from year 1976 to 2016 in three stock market which are Hang Seng, S\&P500 and Nikkei 225.

\begin{tabular}{|} 
Table 1. First cycle during year 1976 until 1987 \\
\begin{tabular}{|c|c|c|c|c|}
\hline $\begin{array}{c}\text { Stock } \\
\text { Market }\end{array}$ & $\begin{array}{c}\text { The } \\
\text { value } \\
\text { of } \omega\end{array}$ & $\begin{array}{c}\text { Market } \\
\text { Value }\end{array}$ & $\begin{array}{c}\text { Intrinsic } \\
\text { Value }\end{array}$ & Bubble Size \\
\hline $\begin{array}{c}\text { Hang } \\
\text { Seng }\end{array}$ & 7.416 & 3949.7 & 363.47 & 3586.23 \\
\hline $\begin{array}{c}\text { Nikkei } \\
225\end{array}$ & 10.690 & 20868 & 8251.24 & 12616.8 \\
\hline $\begin{array}{c}\text { S\&P } \\
500\end{array}$ & 11.657 & 336.77 & 90.82 & 245.95 \\
\hline
\end{tabular}
\end{tabular}

Table 2. Second cycle during year 1988 until 1998

\begin{tabular}{|c|c|c|c|c|}
\hline $\begin{array}{c}\text { Stock } \\
\text { Market }\end{array}$ & $\begin{array}{c}\text { The } \\
\text { value } \\
\text { of } \omega\end{array}$ & $\begin{array}{c}\text { Market } \\
\text { Value }\end{array}$ & $\begin{array}{c}\text { Intrinsic } \\
\text { Value }\end{array}$ & Bubble Size \\
\hline $\begin{array}{c}\text { Hang } \\
\text { Seng }\end{array}$ & 10.51 & 16673 & 2379.1 & 14294 \\
\hline $\begin{array}{c}\text { Nikkei } \\
225\end{array}$ & 11.228 & 20726.99 & 7215.56 & 13511.43 \\
\hline $\begin{array}{c}\text { S\&P } \\
500\end{array}$ & 12.30 & 1186.75 & 1565.15 & 713.98 \\
\hline
\end{tabular}

Table 3. Third cycle during year 1998 until 2008

\begin{tabular}{|c|c|c|c|c|}
\hline $\begin{array}{c}\text { Stock } \\
\text { Market }\end{array}$ & $\begin{array}{c}\text { The } \\
\text { value } \\
\text { of } \omega\end{array}$ & $\begin{array}{c}\text { Market } \\
\text { Value }\end{array}$ & $\begin{array}{c}\text { Intrinsic } \\
\text { Value }\end{array}$ & $\begin{array}{c}\text { Bubble } \\
\text { Size }\end{array}$ \\
\hline $\begin{array}{c}\text { Hang } \\
\text { Seng }\end{array}$ & 9.362 & 28442.8 & 13880.6 & 14562.2 \\
\hline $\begin{array}{c}\text { Nikkei } \\
225\end{array}$ & 7.052 & 26646 & 4571.3 & 22074.7 \\
\hline $\begin{array}{c}\text { S\&P } \\
500\end{array}$ & 12.30 & 1186.75 & 252.05 & 934.7 \\
\hline
\end{tabular}


Table 4. Fourth cycle during year 2008 until 2016

\begin{tabular}{|c|c|c|c|c|}
\hline $\begin{array}{c}\text { Stock } \\
\text { Market }\end{array}$ & $\begin{array}{c}\text { The value } \\
\text { of } \boldsymbol{\omega}\end{array}$ & $\begin{array}{c}\text { Market } \\
\text { Value }\end{array}$ & $\begin{array}{c}\text { Intrinsic } \\
\text { Value }\end{array}$ & $\begin{array}{c}\text { Bubble } \\
\text { Size }\end{array}$ \\
\hline Hang Seng & 12.657 & 31638 & 7923 & 23715 \\
\hline Nikkei 225 & 12.30 & 38916 & 15028 & 23888 \\
\hline $\begin{array}{c}\text { S\&P } \\
500\end{array}$ & 12.30 & 21022.44 & 832.86 & 20189.58 \\
\hline
\end{tabular}

From table 1 until table 4 , we can see that the size of the rational speculative bubble in Hang Seng, S\&P500 and Nikkei 225 are increases from one cycle to another cycle. The trend of the increasing size will be continued if there is no consideration from any party to take part to overcome this problem. This shows that the economic situation is not in a very good condition. The rational speculative bubble might be burst if there are no solutions to be taken to cover up the problem. In conclusion, this study estimates the value and size of the rational speculative bubble from year 1976 to 2016 . The GJLS model successfully applied to the data and achieved the study aim. The data was analyzed by using $\mathrm{R}$ software and Microsoft Excel.

\section{Conclusion}

Economic bubble or financial bubble is a very important issue. It should not be underestimated. It looks like nothing, but when it breaks, it give a tremendous and negative impact towards economic growth. Various searchable solutions to ensure that bubbles do not burst. This can make a secure and stable towards the economic system. In this study, the size of the rational speculative bubble in Hang Seng, S\&P500 and Nikkei 225 Index market from year 1976 to 2016 acquired by using Generalized Johansen-Ledoit-Sornette model. Future study can be done by identifying the next cycle of the bubble collapse.

\section{References}

[1] Dean Baker 2008 The Housing Bubble and the Financial Crisis Centre for Economic and Policy Research,USA ,(2008) 73-81

[2] Efsun Kürüm and Gerhard-Wilhelm Weber and Cem İyigün 2014 Financial Bubbles Springer Proceedings in Mathematics \& Statistic\},73 (2014) 453-468.

[3] Davendran Indiran,Nurfadhlina Abdul Halim Wan Muhammad Amir Wan Ahmad and Mustafa Mamat, An Analytical Comparison between Standard Johansen-Ledoit-Sornette Model and Generalized Johansen-Ledoit-Sornette Model, Applied Mathematical Sciences 8 (2014) 2257-2267

[4] Davendran Indiran,Nurfadhlina Abdul Halim and Wan Muhammad Amir Wan Ahmad, Hong Kong Stock Market's Rational Speculative Bubble Periods 2008, International Journal of Applied Research 1,10 (2015) 863

[5] Vincenzo Liberatore, Computational LPPL Fit to Financial Bubbles, (2010).

[6] Cate Reavis, The Global Financial Crisis of 2008: The Role of Greed,Fear and Oligarchs,MITSloan Management, (2012) 09 093

[7] Kimberly Amadeo,2008 Financial Crisis: Causes, Costs, Could it Reoccur (2017) Retrieved from: https://www.thebalance.com/2008-financial-crisis-3305679

[8] Sher Verick and Iyanatul Islam, The Great Recession of 2008 2009: Causes, Consequences and Policy Responses. IZA Discussion Paper No. 4934, (2010)

[9] Nurharyanti Borhan, Nurfadhlina Abdul Halim and Wan Muhammad Amir W. Ahmad, Rational Speculative Bubble Size in Gold,Hang Seng, S\&P500 and Nikkei 225 Index During Year 2008 to 2016. IOP Conference Series: Journal of Physics Con$\begin{array}{llll}\text { ference Series } 890 & \text { (2017). Retrieved from: }\end{array}$ http://iopscience.iop.org/article/10.1088/17426596/890/1/012166/pdf 